\title{
Toward an Ethnomusicology of the Early Music Movement: Thoughts on Bridging Disciplines and Musical Worlds
}

\section{Citation}

Shelemay, Kay Kaufman. 2001. "Toward an Ethnomusicology of the Early Music Movement: Thoughts on Bridging Disciplines and Musical Worlds." Ethnomusicology 45 (1): 1. doi: $10.2307 / 852632$.

\section{Published Version}

$10.2307 / 852632$

\section{Permanent link}

http://nrs.harvard.edu/urn-3:HUL.InstRepos:34872755

\section{Terms of Use}

This article was downloaded from Harvard University's DASH repository, and is made available under the terms and conditions applicable to Other Posted Material, as set forth at http:// nrs.harvard.edu/urn-3:HUL.InstRepos:dash.current.terms-of-use\#LAA

\section{Share Your Story}

The Harvard community has made this article openly available.

Please share how this access benefits you. Submit a story.

\section{Accessibility}




\title{
Toward an Ethnomusicology of the Early Music Movement: Thoughts on Bridging Disciplines and Musical Worlds
}

\author{
KAY KAUFMAN SHELEMAY / Harvard University
}

$\mathrm{E}$ thnomusicology has long occupied what might be termed a "liminal" ties, and the social sciences, ethnomusicology has long held the ambiguous, middle ground between historical musicology and anthropology. If anthropology provided the methodological tools for musical ethnography, a heterogeneous world of musical performance contributed the sounds, settings, and significances that ethnomusicologists have sought to document and understand. Yet while ethnomusicology absorbed theories from across the disciplines, ethnomusicologists in North America have continued to find their most secure institutional homes not within departments of anthropology, linguistics, cultural studies, or as area specialists, but within schools of music and music departments. Finally, while questioning power inequities within the societies they study and interrogating their discipline's colonial roots, ethnomusicologists have continued to pursue studies of "other" musics-musical traditions that in some way stand outside the world of the Euro-American classical tradition, whether these boundaries are defined by geographical origins, transmission patterns and technologies, or socio-economic positions. In the following essay, I would like to offer a preliminary ethnography of the early music movement, drawing from it what I hope are useful insights into the collapsing musical boundaries in our changing world and the new agendas that might unite musical scholarship through a shared pedagogy and practice of musical ethnography. To this end, I will preface my case study with a brief disciplinary overview and return to this broader perspective in the conclusion. ${ }^{1}$

(C) 2001 by the Board of Trustees of the University of Illinois 


\section{Ethnomusicology, Ethnographic Method, and "Non-Western" Music}

In an introduction to a special issue of the Journal of the American Musicological Society (JAMS) published in 1995, Regula Qureshi discussed the relationship between anthropology, history, and a broader musicology that includes ethnomusicology. Qureshi characterizes the "anthropologizing of music history," the primary and most productive relationship to date of anthropology and historical musicology, as beginning with "a recasting of the musical product into the realm of experience" (Qureshi 1995:335). The four essays that follow Qureshi's introduction interrogate music in culture through highlighting the notions of "dialogue, de-essentializing, and difference" (Qureshi 1995:339). Indeed, the special JAMS issue builds on historical musicology's growing engagement with a range of anthropological theories that have served to enliven and enrich the musicological palette, forecast earlier in writings by Tomlinson (1984) and Treitler (1989).

Ethnomusicologists, of course, have drawn freely on anthropology; indeed, they have spent much of the second half of the twentieth century trying to remake their own discipline in its image. To note just a few milestones, one might cite Merriam's Antbropology of Music (1964), Alan Lomax's Cantometrics (1976), Timothy Rice's remodeling of ethnomusicological theory (1987) based on readings of Clifford Geertz, and Mark Slobin's schema for transnational musics (1993) which draws upon Arjun Appardurai's notion of "ethnoscapes" (Appadurai 1990). Ethnomusicological research and writing have further interacted closely with a number of different streams of anthropological thought, ranging from structuralism, to symbolic, linguistic, and reflexive anthropology. While none of these efforts has resulted in a new theory that moves beyond its anthropological mod$\mathrm{el}$, there have been, particularly recently, a number of increasingly nuanced case studies.

Yet there is one area allied to anthropology in which ethnomusicologists alone have innovated. I have earlier suggested (Shelemay 1996b) that the domain of ethnographic method is where ethnomusicologists have most successfully and creatively occupied a disciplinary space midway between anthropology and musical scholarship. One is tempted to dub this a true "anthromusicology." But since terminology is already so problematic, I will draw instead on a distinction made over a decade ago by Anthony Seeger (1987). While historical musicologists are now beginning to participate actively in an "anthropology of music," bringing the "concepts, methods, and concerns of anthropology" to studies of music history, ethnomusicologists have in the meantime moved much more aggressively toward what Seeger has termed a "musical anthropology," exploring the way[s] "musi- 
cal performances create many aspects of culture and social life" (1987:xiii). I believe that the ethnomusicological adaptation and transformation of the ethnographic method to the study and experience of musical act and sound provide the key to explore these formative processes set into motion through musical invention and performance. Here ethnomusicologists have carved out a special relationship to anthropological theory and method from which historical musicologists could potentially benefit. This is a juncture where a partnership between ethnomusicology and historical musicology could prove fruitful, yet neither side has yet capitalized on its possibilities.

The JAMS issue on music anthropologies and music histories also suggest future possibilities that bridge disciplinary boundaries. All four grapple substantively or indirectly with ethnographic dilemmas: One raises questions highlighted during the fieldwork process (Monson), a second critiques ethnography and resulting interpretations of others (Agawu), and the two final contributions (Tomlinson, Feldman) seek to re-imagine insiders' perspectives, through lenses of poststructuralist and ritual theory respectively, of the distant worlds of Aztec song and opera seria. While Monson and Agawu, both of whom have done fieldwork in the traditions they discussed, explicitly address the ethnographic process, Tomlinson's and Feldman's essays move more directly to anthropological theory, side-stepping exploration of the ethnographic encounter. This is unfortunate, if one agrees that not only does "fieldwork constitute ethnomusicology," but that the ethnographic experience can be viewed as a pathway to experiencing and understanding music, as well as to ask what it is like for a person to make and to know music as lived experience (Titon 1997:87).

If disciplinary boundaries between anthropology, ethnomusicology, and musicology overlap, these boundaries are nevertheless maintained by a longtime divide between musics studied. However, the ethnographic challenge of distinguishing musical boundaries between the West and the Rest raises a number of possibilities for new, shared fields of inquiry. I will address this issue as it arises with regard to the early music movement below, but here would offer a few broader comments on the conceptualization of "non-Western music" vs. "Western music" and the manner in which I believe this opposition must be collapsed if we are to traverse successfully the divide between historical musicology and ethnomusicology and make more fruitful the relationship of both to anthropology.

Anthropology's and ethnomusicology's longtime historical engagement primarily with materials and musics from outside of Europe and North America has led to a close association of both of these disciplines with the unfamiliar, conceptualized within a framework of difference, and often characterized as exotic. This perspective has been further exacerbated by a 
tendency to assume isomorphism between space, place, and culture (Gupta and Ferguson 1992). The recent rethinking of totalizing and bounded notions of culture has fallen on sympathetic ears in ethnomusicology none too soon, coinciding with the movement away from foreign fieldsites to the study of a variety of musics "at home" as well as the increasing investigation of popular and transnational styles. Yet the longstanding binary division of music into categories of "Western" and "World Music" has not really been challenged head-on and will not be dismantled by a simple change of field venues. That ethnomusicologists have largely remained silent on this issue can be attributed perhaps to their desire to preserve clear boundaries between their own pursuits and identity in the face of an overwhelming presence, at least in most American academic institutions, of "Western" musical traditions traditionally performed and studied.

On the ground, wherever scholars actually practice a musical ethnography, it is becoming increasingly difficult to discern where boundaries conceptualized and named geographically can in fact be drawn (Shelemay 1996a). This is true of virtually all musical traditions, whatever their historical provenance, locale, human networks, class associations, economic settings, or transmission patterns. That most "Western" of musics, the twentieth-century Euro/American orchestral tradition, has long been influenced by multiple musical traditions, practiced by an international array of performers and composers, and appreciated by aficionados stretching from Boston to Tokyo. Similarly, popular musics largely dispersed through the media of recordings, radio, and concert tour have crossed so many musical and social boundaries that they can no longer be partitioned. Witness the transformations of Sufi qawwali, which exists variously as devotional song and secular concert genre in Pakistan while constituting a popular, commercial genre abroad (Sakata 1994:89). Even what have been termed "subcultural musical sounds" (Slobin 1993) attached to particular local or ethnic communities are in actuality both heterogenous and international. Here I would cite the repertory of paraliturgical hymns transmitted, performed, and still actively composed Syrian Jews from New York to Buenos Aires, who set sacred Hebrew texts to melodies variously borrowed from mass-distributed Arabic films and recordings, North American popular songs, and the compositions of Beethoven and Rachmaninoff. (Shelemay 1998) The categories of "Western-music" and "non-Western music" have disintegrated, if indeed these rubrics ever had the integrity with which they were invested by scholars. The complex of musical activities, traditions, and musicians I will discuss (termed "early music" by both its practitioners and a wider community internationally), is among those commonly categorized as a subset of Western music. That this categorization once again poses 
problems is not surprising and will enter in important ways into the discussion below.

The acknowledgment of the "other" in anthropology (usually discussed in musical scholarship in reference to "non-Western" musical traditions) has recently been extended to characterize unfamiliar aspects of the past in a variety of historical disciplines (such as Lowenthal 1985). Thus Gary Tomlinson has written that

I began my study of Renaissance musical magic, then, with a keen sense of its distance, its unfamiliarity, its otherness. This sense linked the project from the first with anthropological thought. (Tomlinson 1993:4)

Yet the idea of otherness, which has attracted some historical musicologists and which has led them to explore creatively the anthropological literature, has served only to erect barriers to a true discourse with ethnomusicologists, who in the past applied their ethnographic techniques primarily to musics outside the West and only on rare occasion discussed the "Western" art music tradition. A true musical anthropology would seem to hold great potential for the study of "Western music" as well, yet this venture has been less actively contested than trivialized or ignored. Bruno Nettl has summarized the range of responses to his own efforts to carry out an ethnography of classical music culture in American Schools of Music (Nettl 1995:xi-xii), noting that Western classical music is the "last bastion of unstudied musical culture." His work, along with that of Henry Kingsbury (1988), Philip Bohlman (1989), and Ruth Finnegan (1989), provide fine examples of ethnographies of music schools and conservatories, chamber music as ethnic music, and music of an English urban area. However, the growing musicological literature informed by anthropology generally omits any reference to this type of ethnomusicological activity. Yet fewer historical musicologists have themselves experimented with ethnographic method or have drawn upon its data in the context of their own research designs. ${ }^{2}$

Here we arrive at a juncture where both ethnomusicology and historical musicology are missing a grand anthromusicological opportunity. It is the possibility and potential of the convergence of historical musicology and anthropology, with the experience of ethnomusicology as mediator in the realm of ethnographic method, that leads me to explore this prospect through discussion of a recent ethnography of the early music movement in Boston. My purpose in the next section of the paper is to provide enough basic information about both the ethnographic process and the materials it gathered to explore some of the potentials and pitfalls of ethnomusicologies of "Western music" and the role that ethnomusicologists could play in moving musical scholarship further in these directions. 


\section{In Search of "The Lost World"}

"Things ain't what they used to be and they never were." (Joel Cohen, 1 October 1996) ${ }^{3}$

In early June of 1997, Steven Spielberg's blockbuster movie "The Lost World" opened in Boston and the public was treated to visions of a dinosaur running amok in Los Angeles. A few days later, on June 10, 1997, the ninth Boston Early Music Festival (BEMF) began, a week-long, biennial gathering where thousands of practitioners and afficionados of the early music world swarmed over the Boston landscape, attending hundreds of virtually round-the-clock concerts throughout the metropolitan area, viewing displays and demonstrations of period instruments of all types, and frequenting a commercial exhibit featuring everything from the latest recordings and editions to custom-made theorbo cases. I draw the analogy between "The Lost World" and the BEMF not because either seeks to resurrect a lost past, but because of the manner in which both of these endeavors construct and transform the past in the present, whether bringing rampaging, maternal dinosaurs to the screen or mounting a very post-modern production of a seventeenth-century opera (Luigi Rossi's "L'Orfeo"). If both are ostensibly in search of "lost worlds," they are also very active agents in that search, constituting cultural productions that have substantial symbolic and economic force, sophisticated aesthetic agendas, and an impact well beyond their respective "worlds" of cinema and music.

During the 1996-1997 academic year, I collaborated in a team research project centered at Harvard on early music in Boston. The ethnographic process actually began a full half-year before, as I, with my partners in this venture, historical musicologist Thomas Forrest Kelly and ethnomusicologist Carol Babiracki, planned the project, negotiating with each other and individuals active in the early music movement to establish a fieldwork plan for the coming fall. Our goal was to begin to chart the boundaries, workings, and participants of the early music world as constituted in the late 1990 s in Boston, which has long served as the primary American center for such activities. We envisioned the 1996-1997 iteration as the first stage in a longer-term research effort. In collaboration with a group of eighteen graduate and undergraduate students, ${ }^{4}$ we carried out ethnographic research within the context of an intensive fall 1996 seminar, supplemented by a year-long "workshop" attended by class members, additional graduate students, and others in the Harvard community interested in early music. We worked primarily with four ensembles considered by themselves and others to be active in the early music movement. The groups were 1) Tapestry (a vocal ensemble of four women who sing primarily medieval selections); 2) The Voice of the Turtle (a four-person instrumental/vocal ensem- 
ble which performs mainly a Sephardic song repertory with its historical roots in the Renaissance); 3) The Boston Museum Trio (a Baroque instrumental trio); and 4) The King's Noyse (a Renaissance string consort). Each of these four groups participated in class presentations and interviews, a process followed up (except with the King's Noyse because of scheduling problems) by more focused ethnographic inquiry undertaken by a small team of students. The teams, each supervised by one faculty member, carried out further individual and group interviews, attended rehearsals and concerts, administered audience surveys, and gathered additional primary and secondary materials ranging from old programs to published recordings. I would note that our efforts also included a survey of and attendance at a cross-section of early music concerts in Boston during fall 1996, ${ }^{5}$ and, throughout the entire 1996-1997 academic year under the auspices of the workshop, a series of presentations by and interviews/discussions with a number of other individuals active in the early music movement, including prominent instrument makers and instrumentalists, leaders of major ensembles, and a number of musical professionals and amateurs. In drawing on these materials for this essay, I acknowledge the collaborative efforts of my faculty and student colleagues as well as the cooperation and knowledge of so many members of the early music community in Boston. ${ }^{6}$ I would mention here that many of the quotations included below are taken from informal, spoken discourse and reflect the impromptu and informal venue in which they were made. ${ }^{7}$

It should also be noted that, due to the involvement of members of the research team as performers and scholars of early music, and the academic backgrounds and current affiliations of many in the early music movement, the distinction between ethnographer and research associate was more often than not blurred. Indeed, exploring and coming to terms with the overlapping professional and personal networks as well as shared life venues and values proved to be one of the most challenging aspects of this project. It deserves much more careful attention and analysis and is the subject of some further discussion below. One member of our faculty team, medievalist Thomas Kelly, has been a generative figure in the early music movement, directing period ensembles and productions, involved in numerous early music organizations, and producing editions. Among the student members of the team were several musicians who performed professionally in Boston and elsewhere, and others who were active in studying and editing repertories relevant to the early music movement. Of our colleagues who directed or participated in the ensembles with which we worked, several are faculty members at our own and other Boston educational institutions. The close and symbiotic relationship between those active in the early music movement and the scholars who were ostensibly studying the 
scene provided a challenging venture in "insider" ethnography as well as an unusual opportunity to critique the relationship of scholarship to the "real world" of music. While ethnographers have been criticized in the past for constructing "the Other" in terms of spatial and temporal distance (Fabian 1983:xi), such a separation would not have been likely to arise in a study such as our own. Rather an opposite problem arose, traces of which can be found throughout the interview transcripts and in fieldnotes: Here ethnographers and practitioners shared time, place, and institutional lives to the extent that the borders between the identity of researcher and subject in the early music study can only be described as blurred. Interviews sometimes slipped into conversations or even into spirited debates as members of the research team became at once musicians, audience members, or occasionally, critics. Early music practitioners, speaking from their own experiences, referred often to the scholarly literature and critical editions, which they know intimately and on which they draw in preparing detailed notes for concert programs and published recordings. One day members of the research team welcomed figures from the early music world into our classroom as expert informants. The next, they interacted with these same individuals over coffee, by telephone, or e-mail, alternately soliciting further advice or exchanging information on issues of performance practice or repertory. If the ethnographer is inevitably implicated in "making" his or her subject, the study of the early music movement provides an unparalleled opportunity to critique not just the workings of a remarkable musical subculture, but much of the course of the scholarly enterprise so heavily implicated in its making.

\section{What is "Early Music"?}

What is early music and what are its boundaries? In an unpublished summary of a survey of the early music movement sponsored by the membership organization Early Music America, Thomas Kelly wrote that "the field would seem to comprise three related elements: a body of music, those who perform it, and the way(s) in which the performers approach the music" (Kelly 1989:2). Yet, as Kelly notes, "as the early music revival continues apace, however, definitions and boundaries of all types change, become indistinct, or fall away altogether" (ibid.). There is a substantial background to the present-day movement dating back to the nineteenth century that I cannot address in detail here, but which was explicated in an article by Howard Mayer Brown, whose lead I will follow in glossing "early music" as "an interest and involvement with the music of the past" (1988:30).

But what type of involvement do we find with music of the past? And which pasts? Our project intended to incorporate inquiry into aspects of 
musical performance, but to also move beyond it to explore more deeply the social and cultural factors that have rendered "early music" a living tradition in the twentieth century. If there is a widespread assumption that the basis of early music activity is a search for "historical faithfulness to the past" (Kenyon 1988:6), both the literature and ethnographic inquiry present strong challenges to that view. Ethnographic research tends to support perspectives such as that of scholar/performer Laurence Dreyfus, who has written that early music is a late twentieth-century ensemble of social practices, signifying "first of all people and only secondarily things" (Dreyfus 1983:298). Musicologist Richard Taruskin, himself a longtime performer of the Renaissance repertories, has perhaps most clearly set forth a view that contextualizes the complex relationship of the early music movement to the past, to a contested world of historically-informed performance practice, and to the values of the late twentieth century:

I am convinced that "historical" performance today is not really historical; that a thin veneer of historicism clothes a performance style that is completely of our own time, and is in fact the most modern style around; and that the historical hardware has won its wide acceptance and above all its commercial viability precisely by virtue of its novelty, not its antiquity. (Taruskin 1988:152)

This perspective is echoed by individuals active in Boston early music circles. Joel Cohen, the director of the Boston Camerata, noted in an interview that

I would rather not use the word "early music" now. I think it's more a question of how you approach performance and I try, when I perform ... to place it in a historical context. You know ... to find out what the surrounding values are. And in that sense, it's-as Taruskin correctly points out, ${ }^{8}$ it's a ... modernist approach, 'cause nobody ever did that before-[they] just played ... I'm not so sure there's a movement, but there's still early music going on ... I think a lot of people went into it . . because they could make it theirs ... I wanted to do something which would leave me some space. (Joel Cohen, 1 October 1996)

Thus the early music movement, while drawing on music of the historical past, is powerfully informed by the creative impulses of its practitioners and the aesthetics of the present. Yet the "otherness" of the past remains ever-present, both a motivating force and strong drawing card for some practitioners and many in the audience (as well as critics in the media), who revel in productions of works "you read about in the history books but never hear" (Tommasini 1997:17). However, this "otherness" is inevitably and sometimes dramatically inflected by a late twentieth century sensibility, with difference articulated by many as a central value of the movement at large.

Present-day creativity thus joins with historical awareness and operates 
actively in all domains of program planning and performance practice. For example, violinist Daniel Stepner noted the creative role of members of the Boston Museum Trio, consisting of himself, gambist Laura Jeppesen, and keyboardist John Gibbons, in such basic and little discussed processes as selecting and formulating their own repertory:

There's lots of music that's appropriate for us to play together, but very little, relatively little music that was written specifically for these instruments. (Daniel Stepner, 22 October 1996)

Furthermore, each performance of a composition is an innately creative act:

Laura and I were playing the two lines that Bach wrote, and John was filling in the harmonies, but he was also inventing a third voice a lot of the time, particularly in the slow movement, and to me that's in a way one of the exciting things about this music is that there's a lot of room for improvisation. . . I did a few little decorative improvisations but there was some real invention going on in the keyboard playing which doesn't get noticed, and talked about much. (ibid.)

While their performances are certainly "historically informed," the Boston Museum Trio is at the same time "re-inventing" music of the past, a process acknowledged as an imaginative and exciting one:

I think the beauty and attraction of early music is that we don't ultimately know, despite all the notation... [how] it sounded. We have to recreate it. And through the filter of our imaginations and personalities. And that's what's so challenging and exciting about music that hasn't been recorded yet or music for [which] there are no recordings by the composer. (Daniel Stepner, 29 October 1996)

Musicians in all of the ensembles with which we worked testified to the centrality of creative activity in their conceptualization and performance of musical repertory. For example, the founder of the King's Noyse, a Renaissance string band active since 1987 , noted that

I could just say this is a twentieth-century phenomenon. In many ways I do. This is a twentieth-century thing. What I enjoy doing the most is repertoire from the sixteenth century and I enjoy the parameters of sixteenth-century reaction, and I try to stick to those, but I think of it as being a music of now. And I've often thought about doing violin band arrangements of modern tunes ... you want to just do the Beatles and put out a Christmas album and finally make some money. You know, it would still be a Renaissance violin band and would draw from popular music genres and make it a twentieth-century event. (David Douglas, 5 November 1996)

\section{What is the Early Music Movement?}

From an ethnographic perspective, the early music movement can be seen less as a bounded stream of musical discourse than a multi-faceted 
world of musical and cultural experience. In terms of conventional parameters of time and space, one finds a virtually unlimited array of musics and musical practices from a full range of accessible historical styles primarily emerging from Europe and America, but infused both in the past and present with many cross currents. Here Joel Cohen's invocation of the metaphor of the blind man and the elephant serves nicely to summarize the challenge of providing an overview of this complex phenomenon:

I'm sure we've got pieces of the elephant ... somebody's touching the elephant's tusk, somebody's got his tail, nobody's got the whole elephant, you know. So ... we're sharing elephantology with these guys. (Joel Cohen, 1 October 1996)

In a presentation to the Harvard early music seminar, Cohen set forth a series of rubrics that help to "map" the early music movement, at least from the perspective of its participants from the 1960s forward in the northeastern United States. I will draw here on Cohen's categories, with some reorderings and with added discussion of musical instruments, musical values, and socio-economic domains. I am interested to establish a concise framework for theoretical and methodological remarks as well as to provide a backdrop, however sketchy and incomplete, against which my conclusions can be evaluated. An "elephantology" of the early music movement can usefully begin with the following eight points, each of which was present in the materials and observations of our fieldwork ; deeper historical perspectives and further documentation can be gained from writings of Dreyfus 1983, Haskell 1988, Kenyon 1988, and Taruskin 1995.

\section{Amateurism and Professionalism}

Several of our research associates noted that the Boston early music movement had its root in the world of musical amateurs, with a "push toward professionalism" beginning only in the 1960s. The arrival of "outsiders" such Arnold Dolmetsch from Europe (in 1905) to participate in the manufacture of harpsichords served as a catalyst for Boston-based early music activities, as did the later presence of others who helped found organizations such as the Cambridge Society for Early Music (Friedrich Von Huene, 24 September 1996). ${ }^{9}$ The Boston Chapter of the American Recorder Society, founded in early 1956 , encouraged amateur musical performance, and its concerts accommodated a wide range of both historical and modern repertory. Indeed, in order to gain wider recognition for the recorder, the Recorder Society commissioned recorder works from contemporary composers. Amateur musical groups proliferated, such as an ensemble for recorders, voice, lap harp, viol, lute, and guitar, called "The Cantabrigians," a clever appropriation of the name by which Cambridge residents are known (Arthur Loeb, Oral History prepared for Archive of Viola da Gamba 
Society, typescript). By the 1970s, however, the movement took a turn toward professionalism and increasing specialization.

\section{Specialist Performers}

Boston provided a congenial location for professional musicians, many of whom found homes at area educational institutions or with firms of instrument makers. Outstanding early music musicians who made Boston home included harpsichord virtuoso Ralph Kirkpatrick, organist E. Power Biggs, and numerous others. ${ }^{10}$ Many musicians gravitated to Boston after graduating from music schools elsewhere and studying in Europe; the plethora of musicians and possibility of a variety of work opportunities in the early music domain were important attractions (Dan Stepner, Laura Jeppesen, 29 October, 1996).

Most of the professional musicians with whom we worked, despite a close association with a primary ensemble, also performed with several other groups. While a few specialize in the music of a particular period, most participate in a range of repertories, shifting playing techniques and even instruments as appropriate. For example, violinist Daniel Stepner is a founding member of the Boston Museum Trio and performs with the Boston Baroque. Yet he also plays with the Lydian String Quartet, a classical quartet in residence at Brandeis University, and for Boston Music Viva, a contemporary music group. Stepner's activities bring to life Laura Jeppesen's remark that

Our trio repertory is not everything to us. We each have a life that is-or a musical life-that is completely apart from the trio... We all are autonomous. (Laura Jeppesen, 21 October 1996)

\section{Instruments}

Although there are some ensembles that are almost exclusively vocal (such as Tapestry), central to the early music movement are musical instruments, particularly the period reproductions made by an impressive number of instrument makers. Many of our associates provided considerable detail about their instruments, conveying not just extraordinary technical knowledge, but the instrument's history and social significance with great elegance. Laura Jeppesen began her own detailed narrative about her career by first introducing her "designer gamba," about which she acknowledged wishing she could see "lined up" with all the people who have played it (Laura Jeppesen, 22 October 1996). Jeppesen proceeded to give a long discourse on the history of the viola da gamba and its repertory, which I cite in part here: 
When you talk about the history of the instrument it's interesting that its heyday was in a different country at a different time. So in the sixteenth century ... we would look at Italy . . . and then Italian gambists went to England. Seventeenth century England is very interesting for the gamba-where the gamba was a . . social instrument. It was owned by landed gentry. . . The French used the gamba in different ways. Louis (XIV), who was the great connoisseur ... who had fine, discerning taste, surrounded him(self) with the best musicians, artists of his time. ... Germans came to the French court to listen and study. ... So the gamba stayed really within the confines of the eighteenth century until its revival. (ibid.)

In this context, it is notable that David Douglas of the King's Noyse defines his group not so much by its repertory, but by its musical style and distinctive instrumental composition of a "Renaissance violin band, meaning a consort of the violin family":

Another important difference about the King's Noyse besides how we play is literally the instruments that we play. The instruments in the sixteenth century were most ideally made as one consort. . . The violin family was best heard as a consort designed to sound and blend with one another. . . But you want the instruments, the sound of each of the instruments to lock in together so that it really sounds like one sound from top to bottom. These instruments are copies of instruments that exist in a couple of different places, primarily the Shrine to Music in Vermilion, South Dakota, ... a great collection of instruments in the middle of nowhere. And they are copies of instruments made for Charles IX, in France, in Paris, in the 1570s and 1580s. (David Douglas, 5 November 1996)

Many individuals came to early music through an initial involvement with instruments and instrument collections. Laura Jeppesen was exposed to the viola da gamba at Yale when she worked as a research assistant on a project with gambas in the musical instrument collection. Many ensembles have emerged from association with collections, such as the Boston Camerata, which was founded in conjunction with the musical instrument collection at the Boston Museum of Fine Arts. Today the Museum remains patron to an annual concert series by an ensemble that carries its name, the Boston Museum Trio.

There is an important material culture aspect to the early music movement that revolves around musical instruments, their construction, and performance practices. Not surprisingly, many of our interview sessions incorporated substantial discussion of tunings, bridge positions, and details such as the presence and/or absence of end pins on viola da gambas. Yet these conversations cannot be characterized simply as discussions of technical issues; rather they provided detailed exegeses that connected grounded musical practice (which individuals usually demonstrated) directly to the musical experience itself as well as to other cultural domains. For instance, 
Ellen Hargis of the King's Noyse discussed at length the content of period paintings, which in revealing to twentieth-century musicians that bridges were placed lower on seventeenth century violins, transformed present-day performance and perception of the music from that era (Ellen Hargis, 5 November 1996).

\section{Specialist and Non-specialist Ensembles}

Testimony by a number of research associates sketched a divide between specialist and non-specialist ensembles. Ensembles established earlier on, in the first wave of professional groups in the 1960s, such as New York's Waverly Consort, continue to perform diverse repertories. Joel Cohen, whose Boston Camerata performs and records a wide range of traditions from medieval Christian and Jewish repertories ("The Sacred Bridge," 1990) to American Shaker music ("Simple Gifts," 1995), credits the increasing specialization by early music ensembles largely to the influence of the late Thomas Binkley, who had a distinguished teaching career in Europe and the United States. ${ }^{11}$ The four ensembles with which we worked during fall 1996 can all be classified as specialist ensembles; it is noteworthy that Laurie Monahan, the founder and director of Tapestry, studied with Binkley at Indiana University.

\section{Musical Values and Performance Practices}

That musicians discuss performance practices in detail is no surprise, but the manner in which they were able to articulate details of musical practice as well as values behind them was one of the richest outcomes of the ethnographic process. For instance, while testimony about musical instruments is perhaps more easily rendered because of the easy availability of the instruments themselves, we found that singers also provided nuanced discussions of vocal production as well speculated on the difficult philosophical issues surrounding the voice and textual articulation. Ellen Hargis, who performs with the King's Noyse, and who realized the role of Orfeo in the BEMF revival of the Rossi opera that served as the centerpiece of the 1997 Boston Early Music Festival's musical offerings, provided extensive commentary on philosophical issues related to textual articulation and dialects:

I sort of take a philosophy that despite the conflicting evidence, I have to be a single singer. I have one voice. Even if I were projecting myself back and saying, OK, I'm at some court in the seventeenth century and I'm singing this pile of songs, I probably wouldn't have at that time tried to be five different people from five different districts, but would have made a reasonable approximation and sung in my own voice and my own pronunciation. So that's what 
I sort of try to do now is to come up with a system for whatever repertoire we're doing that works for that language, that work for most of the texts, and of course, we choose texts that go together. I'm not forced to sing wildly different things . . I I will make compromises, for instance. I was once faced with singing an Old French word that was the equivalent of the modern "seul," alone, and the old pronunciation was "sool," which means drunk. . . I thought this will make people giggle, they'll get distracted from the song, it's really not worth being historically accurate in this case 'cause it'll be so distracting to people. So I compromised on that one, I probably sang somewhere in between. (Ellen Hargis, 5 November 1996)

\section{Local Roots and National/International Networks}

If Boston has served as the American center for early music movement during the second half of the twentieth century and is the permanent home of the BEMF, it also has close ties to other places and is an important node in an international early music network. The BEMF itself, in addition to its international biennial festival, presents a year-round concert series mainly featuring ensembles from outside Boston and often from abroad. There is a general acknowledgment of a close and symbiotic relationship between "in town" and "out of town" activity, the latter incorporating touring and recording activities, along with more prestige (Joel Cohen, 1 October 1996).

Many individuals discussed studying in Europe, which in the past carried considerable cultural capital and offered otherwise unavailable training:

When I decided to study the viola da gamba, I knew I had to go to Europe. . . . In those days, you just had to. There were some gamba players here, but the major activity was happening there. (Laura Jeppesen, 29 October 1996)

Jeppesen went on to note that she was the only American student in an broadly international group during her gamba studies in Belgium in the early 1970s, a period when her future Boston Museum Trio colleagues Daniel Stepner and John Gibbons also studied and worked as apprentice performers in Europe. The centrality of the Netherlands to Baroque music performance practice was stressed by Na'ama Lion, a Baroque flute player from Israel who spent three years studying in Holland before settling in Boston (Na'ama Lion, 26 November 1996).

Indeed, it may well be that Boston's old and continuing historical ties to European culture has both engendered and sustained its connection to early music, a relationship characterized by Joel Cohen as "co-dependent." Boston is still viewed by some as "more European feeling than New York" and continues to attract an international array of musicians who come together to comprise local ensembles. One such example is Tapestry, one of whose four members was from Belgrade, a second from Puerto Rico. In 
summary, Boston is "a place where you can make a living as a musician, freelancer ... “ (John Gibbons, 11 November 1996).

\section{Institutions}

Early music life is tightly organized and both individuals and many groups have close ties to Boston institutions. As noted above, some ensembles began in conjunction with instrument collections, notably the Boston Camerata, and later, the Boston Museum Trio, at the Boston Museum of Fine Arts. Several Boston-area institutions have at different times past and present offered early music degree or certificate programs, including the New England Conservatory, Boston University, the Longy School of Music, and Harvard University. Many individuals prominent in the early music scene teach at these institutions, leading to outcomes such as the establishment of the ensemble Tapestry, which emerged in 1994 from the longtime working relationship of Longy faculty member Laurie Monahan with three of her students. Early music activity is also supported as part of extracurricular life on university campuses; a notable example is the early music program in residence since 1976 at Harvard University's Mather House (Elfrieda Hiebert and Na'ama Lion, 26 November 1996).

In addition to the American Recorder Society and Viola da Gamba Society already mentioned above, many other professional associations have active chapters in Boston; these range from the Lute Society of America, to the American Guild of Organists, and other even more specialized groups such as the Intergalactic Double Reed Society.

Several historical Boston churches provide institutional settings for ongoing early music activity, notably the choir of the Church of the Advent (est. 1844) and the weekly performance of Bach Cantatas at Emmanuel Church (est. 1860) (Noel Bisson and Andrew Shenton, 24 February 1997). The First Congregational Church in Cambridge designated Tapestry as its ensemble in residence. Finally, several of the largest Boston music ensembles can be said to constitute institutions in themselves, such as the Handel and Haydn Society, established in 1815.

\section{Social and Economic Factors}

Ethnographic inquiry into the early music movement reveals a complex community, with multiple pathways and networks. The social dimensions and rehearsal processes of different groups can be highly personal and idiosyncratic, as noted in the discussion of the Quadrivium and Voice of the Turtle below.

A provocative, but largely unexplored finding of our preliminary study, is that professional associations in the early music community have given 
rise to real familial and biological relationships. We were surprised at the number of references to musical transmission from parents to children beginning with the example of Dolmetsch himself (Friedrich Von Huene, 24 September 1996) ${ }^{12}$ to that of the children of Mather House early music program founder Elfrieda Hiebert (26 November 1996). The prospects for familial transmission of early music in the future are further enhanced by the marriages of musicians who perform together, including the presence of couples in two of the four groups with which we worked, the Boston Museum Trio and the King's Noyse. One member of the Boston Museum Trio noted, "I think that our trio has the attributes of a good marriage. .. . Well, we have a marriage in it" (Laura Jeppesen, 22 October 1996).

In the economic arena, our research associates were quite outspoken about the challenges to both individuals and ensembles in the late twentieth century music economy. Several commented at length on the existence of extensive governmental and municipal support of early music in Europe and contrasted it to the dearth of official patronage in the United States. Virtually all participants in our study noted that early music audiences were smaller and that revenues from concert were lower than they had been in earlier decades. However, the decline in early music activity was characterized as applying mainly to small groups, while audiences were thought possibly to have grown among more "mainstream" groups (Na'ama Lion, 26 November 1996).

We heard a great deal of the testimony about economic and practical aspects of surviving in the early music world, learning that virtually all ensembles are burdened with administrative tasks and paperwork and must devote a great deal of their time to such practical matters. Virtually everyone spoke to the challenges of trying to make a living amid intense competition in a specialist market. The economic constraints on all groups also served to provoke occasional sharp comments about the few early music groups that have attained a modicum of commercial success. The fact that most musicians play in multiple groups or hold other (often academic) positions can be attributed in large part to economic necessity. Most groups and their individual musicians are also forced to tour in order to schedule the critical mass of concerts necessary to make even a modest living. Events such as BEMF must be considered not just as cultural and social events, but as critical to the economic life of the early music community in Boston and beyond.

The economic network supporting and interacting with the early music groups, individual performers, and institutions includes management agencies, instrument makers, music publishers, and recording companies. In particular, the availability of a current recording can spell the difference in a group's ability to obtain engagements and maintain an active relation- 
ship with their audience between live concerts. Recordings play a particularly crucial role in early music circles by both circulating performances and providing detailed documentation of repertory, texts and translations, performance practices, and the group's statement of purpose. The investment of time and resources necessary to produce a commercial recording is mentioned as a barrier for all but the largest and most well established ensembles.

\section{Is "Early Music" "Western Music"?}

On the surface, early music seems to be the quintessential "Western" musical experience, a living monument to the past of the Euro-American art music tradition. Yet a closer look raises many questions. Take the instrument exhibit at the heart of the BEMF which in 1997 occupied several dozen rooms on a full floor of the Park Plaza Hotel, and in 1999 spilled over into the Radisson Hotel as well. While dominated by keyboard, string consorts, and wind instruments of European origin, one could also find Celtic harps, penny whistles, Native American nose flutes, and ocarinas. One instrument maker (Kelischek Workshop of Brasstown, North Carolina) ${ }^{13}$ noted that "folk and traditional instruments are early instruments, too" (S. Larson 1997:16). Perhaps most strikingly, the theme of the 1999 BEMF was "Music of the Mediterranean," with a program that included a range of Spanish and Ottoman musics.

Many early music professionals are interested in aspects of world music and incorporate it into their world view and performance practice. Joel Cohen has noted that

I think that that's what's unfair about early music, because Indian music is early music-we don't call it early music. Chinese music is early music, Arabic music is. ... I'm interested in other cultures besides European, but the only ones in which I'm personally happy performing is where I can feel like there's something that I share with the other culture. (Joel Cohen, 1 October 1996)

Cohen has in recent years moved to collaborate with Middle Eastern musicians as well. Beyond an explicit involvement with the cross-cultural, one finds a concept of early music performance as collapsing time and space, transcending arbitrary boundaries, and providing a new context in which old musical relationships can be re-evaluated. When discussing a performance of a Baroque suite, Daniel Stepner noted that

The last was, I think, a relatively neat evocation of a rustic dance. And there's a lot of ... time and space travel in this music. I think a baroque suite is often a way of evoking other cultures, other countries, other climes... and this is in a part of that tradition. As in . . coaching the Dumky Trio, Dvorak piano trio [1892] and I always thought the Dumky was a Czechoslovakian dance. In 
fact it's a Ukrainian dance, which the Czechs imported and ... Dvorak was ready because it would become popular in Czechoslovakia in his time. There's a lot of this. There's a lot of ... multi-cultural awareness despite the political boundaries. Ah . . . one, two, three hundred years ago. And this is a testament to that. (Daniel Stepner, 22 October 1996)

If many aspects of the early music repertory are seen as in connection with a variety of other musics, there is also an appreciation that many of the period ensembles and repertories crossed what are in twentieth-century scholarship perceived as clear boundaries. There is also a strong appreciation for the diversity of European musics of the past:

Fortunately, in the sixteenth and seventeenth [centuries] there's a wealth of different kinds of music to explore, and depending on where you're at, Germany, England, Italy, France. We've done a couple of English projects based on ballad tunes, which is what "The Queen's Delight" is, and "The King's Delight," containing both original polyphony from the period that we play and also arrangements of monophonic material. And we've done two Italian projects ... and a couple of German programs. And there's so many different kinds and styles of repertories ... affected by this whole approach of really much more freedom, of not just trying to interpret what's there, but to try and do it as though a professional dance musicians and dance band were performing it. (David Douglas, 5 November 1996)

In the case of the King's Noyse, it is explicitly acknowledged that

the violin consort from the Renaissance, the sixteenth century was a professional ensemble almost entirely. You made your living playing violin for people to dance to and as an entertainment instrument. It was a lot like the role of jazz in our society now. Although there was a lot more because there wasn't a well-defined art music in the sixteenth century-the popular and the art music were sort of one, were more or less connected, and so a lot of the popular music drew from ... what we might consider to be art music formats. And there was just more cross-over than there is now. (ibid.)

One of the most interesting conjunctions of the cross-cultural with the early music movement can be found in the genesis and performance practice of The Voice of the Turtle. This ensemble, formally established in 1978, had its start as part of the Quadrivium Consort, a group founded in 1967 by a most original and eclectic transplant to Cambridge, Marleen Montgomery. ${ }^{14}$ The Quadrivium's activities included group instruction and musical performance at Marleen's home, with all-night sessions involving close listening drawing upon techniques of yoga and meditation as well as eating, drinking, and socializing. Public performances by Quadrivium were infused with ritual, heavily choreographed, and fully exploited the performance space. The musical repertories explored and performed by the Quadrivium were quite varied, ranging from all types of Medieval and Renaissance music to 
Sacred Harp and other folk musics of American and European provenance. While working on Spanish cantigas during 1973-1974, one member of the Quadrivium came across published editions of Sephardic songs, which later became the central repertory of Voice of the Turtle. Ensemble member Derek Burrows mentioned in an interview that the group first experimented with one or two Sephardic songs, which were so well received by their audience that the ensemble slowly moved to a focus on Sephardic music.

Over the last decade, Voice of the Turtle has carved out a distinctive space, describing themselves in their promotional literature as "a non-profit, tax-exempt organization promoting the study and performance of Sephardic, Medieval, and Renaissance music," with album notes referring to their repertory as "folk music passed down by oral tradition." Voice of the Turtle artistic director Judith Wachs compiles the group's repertory through primary research in sound archives in North America and Israel, through use of major published editions of Sephardic song, and through selective use of newly composed songs by living exponents of the tradition. Wachs has also done fieldwork among elderly Sephardic Jews in the United States and Israel, and often plays tapes of original field recordings for the ensemble at rehearsals as they begin to create their own versions of the individual songs. Voice of the Turtle uses a variety of musical instruments to accompany the songs, ranging from a reproduction of a medieval Spanish bagpipe, to a variety of Middle Eastern drums and chordophones. Similarly, the group attempts to keep vocal and instrumental style, as well as harmonic textures, within a range they feel is congruent with a Mediterranean style.

I have gone into considerable detail on the background and activities of the Voice of the Turtle because their inclusion in our study, due to their strong connection with "world music," was a matter of some concern to members of the research team. At the beginning, there was the suspicion that they represented an anomaly in the early music landscape. Yet, ethnographic data demonstrate that this group, still comprised of four of its five original members, in fact shares with many others an interest in, appreciation of, and affinity for connections with the repertories and processes of many other musical traditions. ${ }^{15}$ Somewhat ironically, the Voice of the Turtle also proved to have particularly deep early music roots in Boston, stemming from their genesis in the Quadrivium. The Voice of the Turtle's involvement with world music therefore can be seen as bringing together several streams of tradition they share with others in the Boston early music world: As the legacy of a creative and eclectic leader, Maureen Montgomery; as an outgrowth of the impact of the 1960 s counter culture of the period and place in which they were formed, a broader cultural trend that has not been adequately acknowledged as a generative element in the broad- 
er early music movement; as the outcome of a creative process giving rise to distinctive group identity, repertoire, and performance practice; and as a pragmatic response to the enthusiastic following they began to build among a growing sector of the audience interested in Sephardic music.

While I have stressed the overt connections with and manifestations of world music in early music circles, there is yet another important aspect of early music performance practice that serves to render even performance of familiar historical repertory "other" or "exotic." Laurence Dreyfus has termed this process "defamiliarization," pointing to tendency of early music performances to depart from expected norms of performance practice, at once upsetting conventional expectations and displacing attention from the interpreter on to the composition. Hotly contested performances (some subsequently canonized and distributed in recordings) such as Joshua Rifkin's Bach B Minor Mass (1981) serve not just to "exoticize" Western music, but also to unsettle a classical music establishment heavily vested in "authentic performance." 16

\section{A Comment on "Authenticity"}

Perhaps no single issue has had as lengthy an exposition among scholars concerned with early music than the notion of "authenticity." Here, too, the ethnographic encounter provides a striking counterpoint to the musicological conversation. David Douglas noted that while the early music community is very concerned about whether something is right or wrong, they have a "love-hate relationship" with the word authenticity and shun it ( 5 November 1996). Joel Cohen dismisses the entire conversation with an anecdote:

I had this argument with Tom Binkley once. I said, "What do you mean by authenticity?" He says, "What's an authentic troubadour song? The first time it was done." I said, "Suppose [the singer] had a tummy-ache that day. He may have sung like a pig. It may have sounded much better the next night, you know." (Joel Cohen, 1 October 1996)

While some knowledgeable amateurs do mention "authentic reconstructions" as a mode of performance that "helps to make it more like it might have been" (Arthur Loeb, 26 November 1996), others refer to the expression as "a loaded word," adding that "it is what we don't know that is fun" (Na'ama Lion, 26 November 1996). Laurence Dreyfus was again quite close to the mark when he suggested that here emerges an intense struggle for values, since preferring one interpretation over another "amounts to a manifesto pro or contra authenticity" (Dreyfus 1983:306-8). In this manner, an ethnography of the early music movement provides insight into not just the unsettling of repertories and performance practices, but into 
what Richard Taruskin has summarized as music historians' sensitivities about "some enduring Dolmetsch-inspired mythology, the belated intervention of positivist musicology, and the ideology of our museum culture" (Taruskin 1988:198).

\section{"Early Music" as "New Music”}

A final ethnographic datum brings the discussion of a modern aesthetic of otherness full circle. As we attended a cross-section of concerts during the fall of 1996, the research team noted with interest (not to mention some surprise) that many early music concerts feature newly composed or commissioned works. Particularly prominent were the compositions of Patricia Van Ness, whom we invited to speak to our early music workshop the following spring. On that occasion, Van Ness explained that her association with the early music movement began in 1990 and grew out of her own attraction to medieval music as recreated in the twentieth century and its congruence with her own personal sound aesthetic:

In the Boston area, it has been my fortune to find a wealth of early music musicians whose work seems to exemplify and embody my notions of beauty. They are expert at pureness of tone, focus, the limited use of vibrato, and the delivery of sensuous lines requiring intensity and concentration. (Patricia Van Ness, 12 May 1997)

Van Ness sets to original music her own sacred poems, which she composes in English and has translated into Latin. She explains that Latin honors the medieval tradition, works better than English, "because the use of a translation seems to shroud the immediacy of the text-it becomes a sort of veil ... adding mystery and remove." Thus in the work and commentary of Van Ness that we once again encounter an aesthetic of otherness, a present-day value deeply embedded in the early music movement at large.

\section{Ethnomusicologies of "Western Musics"}

I think early music was a window into history that the standard conservatory training didn't give us. Not only music history, but general history. There's a lot of tangents which have been very exciting, I think, just reading about the history parallel to the music we play. Not musical history necessarily, political history and so on, cultural history, primarily.

(Daniel Stepner, 29 October 1996)

If historical musicologists wish to recast music history into the realm of experience, there is no better way than to gain understanding than to explore such processes as constituted in the present. To make music is to participate not just in symbolic behavior, but in actions shaped by the ex- 
igencies of a given time and place. Ethnography lays bare the multiplicity of factors that shape musical discourse-and the manner in which music itself can shape behaviors and outcomes in other domains. Ethnographic inquiry constantly brings pragmatic, grounded issues into focus:

If you're a professional musician, the bottom line is you have to sell the goods. I mean, people have to really want to be able to dance, and so you have to come up with a way of doing that that accomplishes your goal so you'll be hired back. (David Douglas, 5 November 1996)

Ethnography militates against assumptions about the way things were and, to paraphrase Peter Jeffery, can help us "re-envision the past" differently. It informs the fieldworker about the vagaries of individual initiative, underscoring the reality of divergent perspectives even in the face of seeming unanimity. As an example, take the following exchange between longtime Boston Museum Trio colleagues Laura Jeppesen and John Gibbons (22 October 1996) following their performance of a composition by Marais:

LJ: I think of this music as being the music that you find when you get to the exterior of Versailles-the big chateau. And you go in past the rooms where the great ambassadors were welcomed and you go further in. You get to the rooms where the women are sitting [in] their chambers, writing letters. You go in further... You come to the innermost place where the King sits with his favorite musician-Marais, and maybe Robert de Bizet, theorbo playerand then you enter Louis' heart ... Forgive me, I get very sentimental about him. ...

JG: I never think about that. I never think about such things as people or buildings or anything like that. The music is just too ... distracting.

Ethnographies of living traditions thus provide a rich opportunity to enhance understanding of musical life traditionally viewed only through the lens of written historical sources; as such, they can help guide the music historian, bringing into focus transmission processes and musical meanings as situated among real people in real time. Ethnographies of "Western musics" may serve to collapse both disciplinary and musical boundaries. For historical musicologists, they could provide a venue in which the assumptions of scholarship can be tested and disputed. For ethnomusicologists, ethnographies of "Western music" provide a lively field in which power relations are largely symmetrical, putting to rest ethical issues of longstanding concern. Such research agendas can only be mounted through negotiation, with the ethnographer subject to many of the same pressures and constraints as the "subjects" of any study. For both music historians and ethnomusicologists, many if not most of whom grew up performing historical European repertories, ethnographies of "Western music" render the fieldwork process intensely reflexive. Bringing "Western music" into the 
picture renders ethnographic training a necessary rite of passage not just for ethnomusicologists, but for music historians as well.

I am not suggesting that historical musicologists carry out fieldwork to uncover some imagined residue of the historical past, nor that they need impose "presentist understandings" of artworks (Tomlinson 1984:358). ${ }^{17}$ However, ethnographic study of living traditions could both enhance the historical musicologist's appreciation of the workings of a fully contextualized music culture and expose the interaction between musics and musicians. Here music historians would do well to draw upon ethnomusicologists' experience in studying complex urban musical traditions, transnational musical movements, and the manner in which music and musicians actively construct their own social, political, and economic worlds. Finally, an engagement with ethnomusicological observation and interviewing would provide historical musicologists with a new lens on anthropological theory, placing current theoretical speculation within a methodological framework through which those propositions can be tested

Ethnographic research could test and illuminate several subjects of current interest, for instance, the role of the body in musical performance and perception. An ethnographic approach to live instrumental performance on period instruments enables one to move quickly beyond surface details of construction and performance practice to testimony about aspects of physical sensation and affect. When David Douglas demonstrated a seventeenth-century technique for holding the violin lower on the arm, which he testifies results in a "freer bow arm," he went on to comment that it provided "the same kind of physical freedom that can be associated with the freedom of dancing" (5 November 1996). Douglas' exegesis provided insights into musical performance as a bodily practice that both connects with and shapes human interaction, as well as impinges upon issues of spatial and social control. While paintings and other visual records of musical performance have often been interrogated for insights into the musical construction of social meanings (see, for example, Richard Leppert's The Sight of Sound [1993]), the almost exclusive restriction of historical inquiry to the eye (whether in reading paintings or texts) neglects a rich venue for potential insights. Ethnographic interviews can change our perception of music as a way of life, such as encountering testimony that Arnold Dolmetsch, doyen of musical authenticity, had early musical instruments carved into the balustrade of the central staircase in his Cambridge home (Friedrich Von Huene, 24 September, 1996).

\section{A Postscript and Proposals}

I therefore offer two related proposals: first, that training in broader musicology should necessarily involve ethnographic experience with liv- 
ing musical traditions; and second, that these fieldwork ventures should necessarily include a good measure of research on those very "Western repertories" not often enough the object of ethnographic attention. In realizing both of these goals, I submit that historical musicologists would be well advised to draw upon decades of ethnomusicological experience with musical ethnography and their growing interest in ethnomusicologies of "Western music." I'd also offer a none-too-gentle hint that ethnomusicologists need to emerge from behind a veil of cross-cultural difference and participate in joint ethnographic ventures.

Certainly our nascent study of the world of early music paid rich dividends, stimulating the music historians, ethnomusicologists, and performers alike. Occasionally there were frustrations, such as moments when several members of our team expressed concern that the flood of social and cultural data was threatening to overwhelm the "musical" issues. There were memorable moments for the experienced ethnographers among us, such as when colleagues from an ensemble with which we worked desired (indeed demanded!) a critical response to one of their performances, not ethnographic "neutrality." Yet all, I think it can be said, experienced a good measure of wonder and excitement at encountering living traditions so actively performed and willingly shared, situated within a richly documented history, discussed in such a thoughtful, even poetic, manner, and pursued with extraordinary creativity. David Douglas may have inadvertently spoken for everyone when he reflected that:

I think there are certain things that early music offers to us that involves elements of investigation and discovery. It seems very much like a journey where I don't really know what is going to happen next, it's not well laid out in front of me. And I never know what I'm going to learn that'll inspire . . . open some door of perception that will allow a new feeling about something I've never had before. (David Douglas, 5 November 1996)

\section{Notes}

1. This paper was drafted for and presented at an invitational conference held at Washington University in St. Louis titled "The Sound of Culture: Anthropological Theory and Ethnographic Methods in the Study of Western Music," September 20-21, 1997, sponsored by the Program in Social Thought and Analysis and the Department of Music. I am grateful to Richard G. Fox, Ingrid Monson, Regula Qureshi, Bruno Nettl, Veit Erlmann, Gary Tomlinson, and Robert Kendrick for helpful comments on the draft presented there.

2. Qureshi (1995:337) has noted that Peter Jeffery's Re-envisioning Past Musical Cultures (1992), with its unusual call for an ethnomusicological approach to music of the past, is a notable exception and was conceived during the years Jeffery collaborated with an ethnomusicologist-myself-on a project that in fact worked from ethnographic materials backwards into manuscripts (Shelemay and Jeffery 1993-1997).

3. Here Cohen cites the title of Duke Ellington's "signoff song," performed at his first Carnegie Hall Concert in 1943 (M. Tucker 1993:210). 
4. Student members of the research team included: Michael Barrett, Wesley Chin, Judah Cohen, Caprice Corona, John Driscoll, Aaron Einbond, Alex Fisher, Hubert Ho, Tiwill Huval, April James, Peter Kalmus, David Lyczkowski, Jennifer Morales, Michael Olbash, Judith Quiñones, Julie Rohwein, Charles Starrett, and Andrew Talle. I thank and acknowledge each of these individuals for their special contributions to this project.

5. In preparation for this process, historical musicology graduate student Jen-Yen Chen, who served as assistant for both the seminar and year-long workshop on early music, compiled a listing of early music concerts in Boston from September 20, 1996 to January 19, 1997. Some sixty-four different musical events are included in his list, a number of which were repeated multiple times or extended over a period of several days. I am grateful to Jen-Yen Chen for his assistance in compiling and archiving the materials from our project and to Harvard College and the Harvard Graduate School of Arts and Sciences for the funding that supported this work.

6. However, interpretations and conclusions drawn from these materials and suggestions made for future research are my own unless otherwise attributed.

7. Interviews cited are listed in the bibliography. I am grateful to Joel Cohen, David Douglas, John Gibbons, Ellen Hargis, Laura Jeppesen, Daniel Stepner, Patricia Van Ness, and Judith Wachs for permission to quote from presentations or interview transcripts.

8. See Taruskin (1988:197), where he suggests "that in modern performances, including those modernistic ones I call authentistic, modern audiences have been discovering a Bach they can call their own-or, in other words, that Bach has at last been adapted with unprecedented success to modern taste."

9. Dolmetsch, who was affiliated with Chickering \& Sons, remained in Boston until 1911, when he returned to Europe. See Campbell 1980.

10. Thomas Kelly provided an outline summary of early music in Boston for our first class session which I have drawn on in part here.

11. In 1959, Thomas Binkley, an American, organized the Studio der frühen Musik in Munich, which took "an ethno-musicological approach to performance practice, rather than relying solely on written documentation form medieval Europe" (Brown 1988:49-50). Binkley borrowed practices and instruments from North African and Middle Eastern musicians, resulting in what has been termed "a Mediterranean style" (Taruskin 1988:142). Binkley later returned to the United States, joining the faculty at Indiana University.

12. See Campbell 1980:530, for details of the activities of Arnold Dolmetsch's children in founding organizations such as the Society of Recorder Players (son Carl, in 1937) and Viola da Gamba Society (daughter Natalie, in 1948); children of Carl Dolmetsch have remained active in the early music movement as well.

13. According to the Boston Early Music Festival and Exhibition Program Book (1997:60), Kelischek Workshop imports and exports worldwide a range of instruments from krumhorns to pennywhistles; its associated Susato Press specializes in native American music.

14. This discussion draws in part on "An Ethnography of Voice of the Turtle," submitted as a final project in January, 1997, by a team consisting of Judah Cohen, Caprice Corona, Hubert Ho, David Lyczkowski, and Judith Quiñones for which I served as faculty advisor. I acknowledge them and also thank Judith Wachs of the Voice of the Turtle for permission to quote the original interviews and materials they provided.

15. Voice of the Turtle is also not the only early music group to use ethnographic techniques in search of new repertory and performance techniques. Joel Cohen and the Boston Camerata worked closely with the Shakers of Sabbathday Lake in preparing the compact disc "Simple Gifts: Shaker Chants and Spirituals."

16. A striking example of defamiliarization was witnessed by this ethnographer at the BEMF 13 June 1997 concert of Capriccio Stravagante, a Paris-based ensemble that performs French Baroque Chamber music. The ensemble, citing the precedent of eighteenth-century French sources, seeks to engage the listener "by leading the ear and detouring it with surprises" (Skip Sempé, Program notes for 13 June 1997, in Boston Early Music Festival and 
Exbibition Program Book 1997:220-221). That the intent was also to unsettle the musical establishment is made clear in the notes as well: "The idea of "non-interpretation" developed by certain specialists of the last few decades is a particularly debased tradition. It is the unwillingness either to unite or separate profanity from profundity that has caused the grave misunderstanding and subsequent misinterpretation of certain earlier repertories" (ibid.:221).

17. There have been a number of studies where ethnography of present-day practice in fact makes possible historical inquiry and stands in a direct relationship to past practices. See Shelemay and Jeffery for one such example.

\section{Sources Cited}

\section{Bibliography}

Agawu, Kofi. 1995. "The Invention of "African Rhythm." Journal of the American Musicological Society 48:380-95.

Appadurai, Arjun. 1986. "Introduction." In The Social Life of Things: Commodities in Cultural Perspective, edited by Arjun Appadurai, 3-63. Cambridge: Cambridge University Press.

$\rightarrow-1990$. "Disjuncture and Difference in the Global Cultural Economy." Public Culture 2(2): 1-24.

Bellman, Jonathan. 1998. The Exotic in Western Music. Boston: Northeastern University Press. Bohlman, Philip V. 1989. "The Land Where Two Streams Flow": Music in the German-Jewish Community in Israel. Urbana: University of Illinois Press.

Boston Early Music Festival and Exbibition Program Book, 10-15 June, 1997. 1997. Cambridge, MA: Boston Early Music Festival Inc.

Boston Early Music Festival Exbibition, 8-13 June, 1999. Music of the Mediterranean. Cambridge, MA: Boston Early Music Festival, Inc., 1999.

Brown, Howard Mayer. 1988. "Pedantry or Liberation? A Sketch of the Historical Performance Movement." In Autbenticity and Early Music, edited by Nicholas Kenyon, 27-56. Oxford: Oxford University Press.

Campbell, Margaret. 1980. "Dolmetsch." In The New Grove Dictionary of Music and Musicians, edited by Stanley Sadie, Vol. 5, 528-31. London: Macmillan.

Chen, Bernice K. 1997. Welcome letter. Boston Early Music Festival and Exbibition Program Book, 10-15 June 1997, p. 7. Cambridge, MA: Boston Early Music Festival.

$\rightarrow$ Dreyfus, Laurence. 1983."Early Music Defended against its Devotees: A Theory of Historical Performance in the Twentieth Century." The Musical Quarterly 69:297-322.

Fabian, Johannes. 1983. Time and the Other. How Antbropology Makes Its Object. New York: Columbia University Press.

Feldman, Martha. 1995. "Magic Mirrors and the Seria Stage: Thoughts Toward a Ritual View." Journal of the American Musicological Society 48: 423-84.

Finnegan, Ruth. 1989. The Hidden Musicians. Music-Making in an English Town. Cambridge: Cambridge University Press.

$\rightarrow$ Gupta, Akhil and James Ferguson. 1992. "Beyond 'Culture': Space, Identity, and the Politics of Difference." Cultural Antbropology 7:6-23.

Haskell, Harry. 1988. The Early Music Revival: A History. London: Thames and Hudson.

Jeffery, Peter. 1992. Re-Envisioning Past Musical Cultures. Ethnomusicology in the Study of Gregorian Chant. Chicago: University of Chicago Press.

Kelly, Thomas Forrest. 1989. "Early Music in America. A Report on a survey conducted by Early Music America." New York: Early Music America (typescript).

Kenyon, Nicholas, ed. 1988. Authenticity and Early Music. Oxford: Oxford University Press. Kingsbury, Henry. 1988. Music, Talent, and Performance: A Conservatory Cultural System. Philadelphia: Temple University Press. 
Larson, Susan. "The world of early music." The Boston Globe, 13 June 1997: C13, C16.

Leppert, Richard. 1993. The Sight of Sound. Music, Representation, and the History of the Body. Berkeley: University of California Press.

Lomax, Alan. 1976. Cantometrics: An Approach to the Antbropology of Music. Berkeley: University of California Extension Media.

Lowenthal, David. 1985. The Past is a Foreign Country. Cambridge: Cambridge University Press.

Merriam, Alan. 1964. The Anthropology of Music. Evanston: Northwestern University Press.

$\rightarrow$ Monson, Ingrid. 1995. "The Problem with White Hipness: Race, Gender, and Cultural Conceptions in Jazz Historical Discourse." Journal of the American Musicological Society 48:396-422.

Nettl, Bruno. 1995. Heartland Excursions. Ethnomusicological Reflections on Schools of Music. Urbana: University of Illinois.

$\rightarrow$ Qureshi, Regula Burckhardt. 1995. "Music Anthropologies and Music Histories: A Preface and an Agenda." Journal of the American Musicological Society 48:331-42.

$\rightarrow$ Rice, Timothy. 1987. "Toward the Remodeling of Ethnomusicology." Ethnomusicology 31:469-88.

Sakata, Hiromi Lorraine. 1994. "The Sacred and the Profane: Qawwali Represented in the Performances of Nusrat Fateh Ali Khan." The World of Music 36(3):86-99.

Seeger, Anthony. 1987. Why Suya Sing. A Musical Anthropology of an Amazonian People. Cambridge: Cambridge University Press.

$\rightarrow$ Shelemay, Kay Kaufman. 1996a. "Crossing Boundaries in Music and Musical Scholarship: A Perspective from Ethnomusicology." The Musical Quarterly 7913-30.

$\rightarrow-1996 \mathrm{~b}$. "The Ethnomusicologist and the Transmission of Tradition." Journal of Musicology 14:35-51.

- 1998. Let Jasmine Rain Down. Song and Remembrance Among Syrian Jews. Chicago: University of Chicago Press.

Shelemay, Kay Kaufman, and Peter Jeffery. 1993-1997. Ethiopian Christian Liturgical Chant. An Antbology. 3 vols, with CD. Madison: A-R Editions.

Sherman, Bernard D. 1997. Inside Early Music: Conversations with Performers. New York and Oxford: Oxford University Press.

Slobin, Mark. 1993. Subcultural Sounds: Micromusics of the West. Hanover: Wesleyan University Press.

Taruskin, Richard.1988. "The Pastness of the Present and the Presence of the Past." In $A u$ thenticity and Early Music, edited by Nicholas Kenyon, 137-207. Oxford: Oxford University Press.

- 1995. Text and Act: Essays on Music and Performance. Oxford: Oxford University Press.

Titon, Jeff Todd. 1997. "Knowing Fieldwork." In Shadows in the Field. New Perspectives for Fieldwork in Ethnomusicology, edited by Gregory F. Barz and Timothy J. Cooley, 87100. New York: Oxford University Press.

Tomlinson, Gary. 1984. "The Web of Culture: A Context for Musicology." 19th-Century Music 7:350-62.

- 1993. Music in Renaissance Magic. Toward a Historiography of Others. Chicago: University of Chicago Press.

$\rightarrow-1995$. "Ideologies of Aztec Song." Journal of the American Musicological Society 48:343-79.

Tommasini, Anthony. 1997. "Even at Birth, Opera Wed the Stirring and the Silly." The New York Times, 14 June 1997: Arts 17.

Treitler, Leo. 1989. Music and the Historical Imagination. Cambridge: Harvard University Press.

Tucker, Mark, ed. 1993. The Duke Ellington Reader. Oxford: Oxford University Press. 


\section{Discography}

The Boston Camerata. 1990. The Sacred Bridge. Erato. 1995. Simple Gifts. Shaker Chants and Spirituals. Erato.

The Waverly Consort. 1992. 1492, Music from the Age of Discovery. EMI Classics.

Anonymous 4. 1992. An English Ladymass: Medieval Chant and Polyphony. Harmonia Mundi. The King's Noyse. 1993. "The King's Delight." $17 \mathrm{c}$ Ballads for voice and violin band. Harmonia Mundi.

The Voice of the Turtle. 1994. Under Aegean Moons: Music of the Spanish Jews of Rbodes and Salonika (Paths of Exile Quincentenary Series, Vol. IV). Titanic Records.

\section{Interviews and Oral Histories}

Friedrich Von Huene, 24 September 1996

Joel Cohen, 1 October 1996

Daniel Stepner, Laura Jeppesen, John Gibbons, 22 October 1996

Laura Jeppesen, Daniel Stepner, 29 October 1996

David Douglas and Ellen Hargis, 5 November 1996

John Gibbons, 11 November 1996

Arthur Loeb, Oral History prepared for Archive of Viola da Gamba Society, typescript, and 26 November 1996

Elfrieda Hiebert and Na'ama Lion, 26 November 1996

Noel Bisson and Andrew Shenton, 24 February 1997

Patricia Van Ness, 12 May 1997 